\title{
Distant Lymph Node
}

National Cancer Institute

\section{Source}

National Cancer Institute. Distant Lymph Node. NCI Thesaurus. Code C106042.

A lymph node located distant to the anatomic site of interest. 